\title{
Utilization of Plastic Waste to Solve the Problem in High-Moisture Biomass Gasification
}

\author{
P. Chobthiangtham and S. Fukuda
}

\begin{abstract}
With an increased interest in energy production from biomass through gasification, the properties of biomass that influenced gasification performance have been investigated. One of important properties is the moisture content. Generally, the excessive moisture in biomass is reduced to meet the acceptable level for gasification by an additional pretreatment process which always costs extra investment. One possible alternative is the co-processing of high-moisture biomass fuels with other low-moisture fuels. In this study, the utilization of plastic waste to solve the problem of high-moisture biomass gasification was investigated by mixing the high-moisture rubber woodchip $(27 \%$ M.C. $)$ with plastic waste at various mixing ratios. The results showed a significant improvement of gasification performance. Even at $10 \%$ mixing ratio, the higher heating value of the product gas increased by about $50 \%$ and $25 \%$ compared to the case of high-moisture rubber woodchip (27\%M.C.) and pre-dried rubber woodchip (8.5\%M.C.), respectively. Compared to mixing with rubber waste at the same weight ratio, the plastic waste addition was found to give a better gasification improvement largely due to the higher carbon and hydrogen content in plastic waste. The findings from this study have shown not only that the high-moisture biomass can be used without pretreatment needed, but also an effective solution to plastic waste disposal.
\end{abstract}

Index Terms - Gasification, plastic waste, rubber woodchip.

\section{INTRODUCTION}

Biomass is one of the potential renewable energy sources in many countries worldwide. Biomass utilization not only lowers the dependency of the depleting fossil fuels but also to reduce emissions of $\mathrm{NO}_{\mathrm{x}}$ and $\mathrm{SO}_{\mathrm{x}}$ as well as $\mathrm{CO}_{2}$ [1]. It has extensively been used to fully or partially substitute fossil fuels for heat and power production in combustion boilers. More recently, biomass gasification has increased its popularity mainly due to its wide range of operated capacity, the flexible utilization of fuel gas product, and the potential reduction of gaseous pollutants such as $\mathrm{NO}_{x}$ [2], [3]. Maximizing biomass utilization potential has become the main focus especially in response to the commitment in $\mathrm{CO}_{2}$ reduction in many countries. However, increasing utilization of biomass has some drawbacks due to its poor physical and chemical properties. The high-moisture content is one of the problematic properties, which reduce the energy density of biomass and consequently the achievable reaction temperature. Especially for biomass gasification, which is sensitive to fuel moisture, the performance could be

Manuscript received October 26, 2014; revised January 20, 2014.

P. Chobthiangtham and S. Fukuda are with the Joint Graduate School of Energy and Environment, King Mongkut's University of Technology Thonburi, Bangkok, 10140 Thailand (e-mail: chobpin@gmail.com, suneerat@jgsee.kmutt.ac.th). substantially deteriorated [4]. The biomass with highmoisture content will take longer time to achieve a complete degradation and decrease the $\mathrm{CO}$ evolution which results to the lower heat content of producer gas [5]. Furthermore, the proportion of tar in the product gas would increase due to incomplete cracking [6]. To reduce the moisture content, biomass is typically dried under the sunlight for small-scale applications. However, the requirements of land and constant sunlight make it impractical for large-scale applications and installations of mechanical dryers are needed which leads to an additional investment and operating cost. Other advanced gasification technologies to directly process high-moisture biomass such as plasma gasification [7], [8], hydrothermal gasification [9] have also been studied. However, these technologies have so far only been developed on a small scale and are projected to have very high capital cost when compared to conventional gasification technologies [8].

Alternative technology which can be applied to the utilization of high-moisture biomass fuels is co-processing with other fuels of low-moisture content. Coal, which generally has lower-moisture content and higher heating values, has often been co-processed with biomass and waste to help increase the reaction temperature by reducing the average moisture of the fuel mixture [10]. Co-gasification of high-moisture biomass with waste materials has also been carried out. For example, Kaewluan and Pipatmanomai [11] studied the co-gasification of rubber woodchip with around $30 \%$ moisture content with shredded rubber waste (SRW) in a bubbling fluidized bed. The results showed that the gasification performance and the quality of product gas from co-gasification were significantly improved when compared to the gasification of pure woodchip. At only $20 \mathrm{wt} \%$ SWR addition, the performance was even better than the gasification of pre-dried woodchip of similar final average moisture content. Therefore, co-gasification can be considered an effective solution for not only to utilize high-moisture fuels, but also to dispose wastes with energy recovery.

Plastic waste is one of the materials present in significant quantities in municipal solid waste (MSW) and the majority of it is discarded plastic bags, which is composed of polyethylene or polypropylene. The generation of plastic waste worldwide has been and is expected to increase every year. Considering the vast amount of plastic waste generated and its high heat content with low-moisture content, plastic bag after being separated from MSW can be considered as a high quality fuel. However, gasification of pure plastic waste has been shown to have some operational problems such as difficulties in feeding and technical limitations due to melting [12] and therefore plastic wastes are often co-processed with 
other fuels, [12]-[15].

In this study, the co-gasification of high-moisture rubber woodchip with shredded plastic bag (SPB) was investigated. Experiments were carried out in the $100 \mathrm{~kW}$ th bubbling fluidized bed gasifier using air as a gasifying agent. The effects of air-to-fuel ratio (presented in term of equivalence ratio-ER) and SPB addition ratio on gasification performance and quality of gas product were investigated and compared with those obtained from the pre-dried rubber woodchip. The results were also further analyzed to investigate the effect of added fuel properties by comparing with those from the previous study of co-gasification of high-moisture rubber woodchip with shredded rubber waste (SRW) at the same addition weight ratio [11].

\section{EXPERIMENTAL SECTION}

\section{A. Materials}

This study used rubber woodchip and waste plastic bag as fuels for gasification experiments. As received, the rubber woodchip had very high-moisture content, i.e. $30-50 \%$, and was in average $10 \mathrm{~mm}$ in width and less than $5 \mathrm{~mm}$ in thickness. During storage, the woodchip lost some of its moisture by natural drying. To eliminate the possible effect of fuel particle size as well as to provide consistency of biomass feed rate, the length of chip was reduced to the maximum of $30 \mathrm{~mm}$. The moisture content of low-moisture or pre-dried rubber woodchip and high-moisture rubber woodchip was controlled at $8.5 \%$ and $27 \%$, respectively.

The waste plastic bag, which was separated from MSW, was dried and shredded. The length was approximately the same as the rubber woodchip. The shredded plastic bag (SPB) was then added into high-moisture rubber woodchip at 0,10 , and $20 \%$ by weight, which is denoted as 0,10 and 20\% SPB, respectively. The fuels were mixed thoroughly before the gasification experiment.

The properties of fuels and fuel mixtures were analyzed. The proximate analysis was conducted using the Thermal Gravimetric Analyzer (TGA). The moisture content of the rubber woodchip and the shredded plastic bag were determined following ASTM D4442-07 and ASTM D6980-12, respectively. The higher heating value (HHV) was analyzed by Bomb Calorimeter. The major elemental contents were analyzed by the Organic Elemental Analyzer (OEA: Flash EA 1112, Thermofinnigan).

For the purpose of investigating the effect of added fuel properties, the results from this study were compared with those from the previous study of co-gasification of rubber woodchip with shredded rubber waste [11]. The shredded rubber waste was added into high-moisture rubber woodchip (i.e. $27 \%$ moisture content) also at 0,10 , and $20 \%$ by weight, which was denoted as 0,10 and $20 \%$ SRW, respectively.

\section{B. Experimental Facilities and Procedure}

Because of several advantages, especially fuel flexibility in terms of properties and sizes and the high heat and mass transfer [16], the bubbling fluidized bed gasifier is considered suitable for co-gasification and was chosen for the study. Experiments were carried out in the $100 \mathrm{~kW}$ th bubbling fluidized bed gasifier using air as a gasifying agent. The gasifier was previously developed in this laboratory and has been used for gasification studies of various fuels. It has an inside diameter of $300 \mathrm{~mm}$ and a height of 2,500 $\mathrm{mm}$ above the air distributor. The detailed configuration was already described elsewhere [17] and the experimental procedure is explained briefly as following.

Prior to the start of the experiment, about $25 \mathrm{~kg}$ of silica sand having the average particle diameter of 350 micron was added into the gasifier to serve as bed material. The particle density and bulk density were $2647 \mathrm{~kg} / \mathrm{m} 3$ and $1560 \mathrm{~kg} / \mathrm{m} 3$, respectively. The air at ambient was fed into the gasifier at the flow rate of $74.3 \mathrm{~kg} / \mathrm{h}$, which corresponds to the superficial velocity at $0.24 \mathrm{~m} / \mathrm{s}$. It was above the predetermined minimum fluidization velocity, i.e. $0.2 \mathrm{~m} / \mathrm{s}$, at ambient temperature. The gasifier system was heated up to approximately $800^{\circ} \mathrm{C}$ by liquefied petroleum gas (LPG) combustion. After the LPG was stopped, the fuel started to be fed into the gasifier. The flow rate of air was fixed while the fuel feed rate was varied in the range of $27-40 \mathrm{~kg} / \mathrm{h}$, which corresponded to the equivalence ratio (ER) ranging from 0.26 to 0.48 .

The temperatures along the height of the gasifier were measured and recorded by the data logger for further analyses. To prevent the gas leakage during the experiment, the pressure in the gasifier was controlled to be slightly lower than ambient. The product gas was continuously sampled and its compositions were measured by a series of gas analyzers, including Continuous Emission Monitoring (Servomex 4200 series) and Micro Gas Chromatography (Varian CP-4900). The dry gas heating value in term of higher heating value (HHV) and lower heating value (LHV) were also estimated from the obtained gas composition by using (1) and (2), respectively.

$$
\begin{gathered}
H H V=\left(12.77\left[\mathrm{H}_{2}\right]+12.62[\mathrm{CO}]+39.78\left[\mathrm{CH}_{4}\right]+58.06\left[\mathrm{C}_{2} \mathrm{H}_{2}\right]\right. \\
\left.+63\left[\mathrm{C}_{2} \mathrm{H}_{4}\right]+69.69\left[\mathrm{C}_{2} \mathrm{H}_{6}\right]+\ldots\right) / 100 \\
\begin{aligned}
L H V= & \left(10.79\left[\mathrm{H}_{2}\right]+12.62[\mathrm{CO}]+35.81\left[\mathrm{CH}_{4}\right]+56.08\left[\mathrm{C}_{2} \mathrm{H}_{2}\right]\right. \\
& \left.+59.04\left[\mathrm{C}_{2} \mathrm{H}_{4}\right]+63.75\left[\mathrm{C}_{2} \mathrm{H}_{6}\right]+\ldots\right) / 100
\end{aligned}
\end{gathered}
$$

where the species contents are given in volume $\%$, and their heat of combustion in $\mathrm{MJ} / \mathrm{Nm}^{3}$ [18].

\section{RESULTS AND DISCUSSION}

\section{A. Improvement of Fuel Mixture Properties}

The properties of rubber woodchip (RW) and SPB are presented in Table I. SPB has much higher carbon and hydrogen content, i.e. 83.6 and $14.9 \%$ wt, as compared to 46.1 and $6.0 \%$ wt for RW on the dry-ash-free basis. This higher hydrocarbon content of SPB also leads to a significant increase in HHV by $32.21 \mathrm{MJ} / \mathrm{kg}$ as compared to that of RW.

As mentioned earlier, the moisture content of the high-moisture rubber woodchip (HRW) was controlled at $27 \%$. Taking that into account, the properties of fuel mixtures of HRW with different addition ratio of SPB were calculated and are presented in Table II. The increased proportion of SPB in the fuel mixture from $0 \%$ to $10 \%$ and $20 \%$ helped 
decrease the average moisture content (M.C.) in the mixture from $27 \%$ to $24.3 \%$ and $21.6 \%$, respectively. Furthermore, the higher heating value (HHV) in the fuel mixture also increased from 13.0 to 16.2 and $19.4 \mathrm{MJ} / \mathrm{kg}$, respectively, due to the relatively high hydrocarbon contents of SPB.

TABLE I: FUELS ANALYSIS

\begin{tabular}{lrrr}
\hline \hline Fuels & RW & SPB & SRW $^{*}$ \\
\hline Proximate analysis (\% wt, dry basis) & & & \\
Volatile matter & 88.9 & 99.6 & 66.2 \\
Fixed carbon & 10.0 & 0.0 & 29.0 \\
Ash & 1.1 & 0.4 & 4.8 \\
Higher heating value (MJ/kg) & 13.0 & 45.2 & 37.1 \\
Ultimate analysis (\% wt, dry-ash-free basis) & & & \\
Carbon & 46.1 & 83.6 & 82.9 \\
Hydrogen & 6.0 & 14.9 & 8.9 \\
Nitrogen & 0.7 & 0.0 & 0.3 \\
Oxygen & 47.2 & 1.5 & 3.9 \\
Sulfur & 0.0 & 0.0 & 4.0 \\
\hline \hline
\end{tabular}

* from previous study [11]

TABLE II: FUEL MIXTURES ANALYSIS

\begin{tabular}{lllll}
\hline \hline Fuel mixtures (\% SPB) & \multicolumn{1}{c}{0} & 10 & 20 & 100 \\
\hline Elemental composition (\% wt, wet basis) & & & & \\
Carbon & 33.5 & 38.5 & 43.5 & 83.2 \\
Hydrogen & 4.3 & 5.4 & 6.5 & 14.9 \\
Nitrogen & 0.5 & 0.4 & 0.4 & 0.0 \\
Oxygen & 34.3 & 31.0 & 27.7 & 1.5 \\
Sulfur & 0.0 & 0.0 & 0.0 & 0.0 \\
Ash & 0.3 & 0.3 & 0.3 & 0.4 \\
Moisture & 27.0 & 24.3 & 21.6 & 0.0 \\
Higher heating value $(\mathrm{MJ} / \mathrm{kg})$ & 13.0 & 16.2 & 19.4 & 45.2 \\
\hline \hline
\end{tabular}

\section{B. Improvement of Average Bed Temperature}

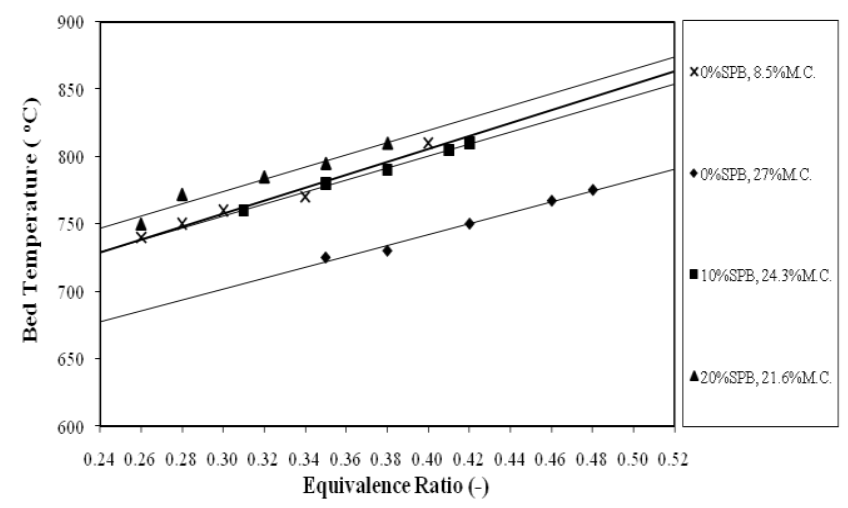

Fig. 1. Average bed temperature at various ERs and proportions of SPB in the fuel mixture compared with that of pre-dried rubber woodchip.

The average bed temperature resulted from the high-moisture rubber woodchip gasification (i.e. 0\%SPB, $27 \%$ M.C.) significantly dropped from that of the pre-dried rubber woodchip gasification (i.e. $0 \% \mathrm{SPB}, 8.5 \% \mathrm{M} . \mathrm{C}$.) throughout the range of studied ERs as presented in Fig. 1. About $50-60^{\circ} \mathrm{C}$ temperature decrease could be observed when the moisture content of the fuel increased from $8.5 \%$ to $27 \%$ due to the higher amount of energy demand for a moisture evaporation, which would otherwise be used by the endothermic pyrolysis and char gasification reactions [19]. This is one of the main effects caused from gasifying high-moisture biomass, which is in line with the results from the other study [4].
An improvement in bed temperature was found when adding SPB into the fuel mixture. The average bed temperature was increased by about 60 and $80^{\circ} \mathrm{C}$ when the SPB proportion was increased from 0 to 10 and $20 \%$, respectively. This is mainly attributed to the decreased moisture content and increases heating value of the fuel mixture with increasing the weight proportion of SPB in the fuel mixture as presented in Table II. The higher the proportion of SPB added, the higher the average bed temperatures for all ERs. It was found that the average bed temperature when gasifying the fuel mixture with $20 \%$ SPB was higher than that of the pre-dried rubber woodchip gasification. Fig. 1 also shows that the average bed temperature increased with increasing ER for all proportions of SPB in the fuel mixture. The increase of ER would increase the rate of the exothermic reaction (promoting the oxidation reaction) resulting in more heat release and the rise of temperature in the gasifier [11], [20].

\section{Improvement of Synthesis Gas Quality}

All the reactions determining the final gas composition for biomass gasification are generally agreed to happen through three steps. The first step called devolatilization or pyrolysis and also called partial gasification which is initiated at low temperature when the thermally unstable components are broken down and evaporate with other volatile components result in char, tar, and light gases such as $\mathrm{H}_{2}, \mathrm{CO}, \mathrm{CO}_{2}, \mathrm{CH}_{4}$, $\mathrm{H}_{2} \mathrm{O}$, as presented in (3).

Pyrolysis reaction:

Biomass + Heat $\rightarrow$ Char + Gases + Vapor or Liquid (Tar) (3)

Then the second step, called oxidation or combustion, starts to take place to provide practically all the thermal energy demanded for endothermic reactions. Oxygen supplied to the gasifier reacts with the combustible substance resulting in the formation of $\mathrm{CO}_{2}$ and $\mathrm{CO}$, as seen in (4) and (5), consequently the reduction of char produced from the first step. The oxidation of hydrogen in fuel to produce steam is also presented by the reaction shown in (6). The reaction shown in (7) and (8) are the carbon monoxide oxidation and methane oxidation, respectively.

Oxidation reactions:

$$
\begin{gathered}
\mathrm{C}+\mathrm{O}_{2} \rightarrow \mathrm{CO}_{2}+\text { Heat } \\
\mathrm{C}+1 / 2 \mathrm{O}_{2} \rightarrow \mathrm{CO}+\text { Heat } \\
\mathrm{H}_{2}+1 / 2 \mathrm{O}_{2} \rightarrow \mathrm{H}_{2} \mathrm{O}(\text { Steam })+\text { Heat } \\
\mathrm{CO}+1 / 2 \mathrm{O}_{2} \rightarrow \mathrm{CO}_{2}+\text { Heat } \\
\mathrm{CH}_{4}+2 \mathrm{O}_{2} \rightarrow \mathrm{CO}_{2}+2 \mathrm{H}_{2} \mathrm{O}+\text { Heat }
\end{gathered}
$$

And in the last step, the gasification reactions of the remaining carbonaceous residue happen with steam and carbon dioxide as seen in the reaction shown in (9) to (11). Methane could also form in the gasifier by the reaction shown in (12).

Water gas reaction:

$$
\mathrm{C}+\mathrm{H}_{2} \mathrm{O} \rightarrow \mathrm{CO}+\mathrm{H}_{2}-\text { Heat }
$$


Boudouard reaction:

$$
\mathrm{C}+\mathrm{CO}_{2} \rightarrow 2 \mathrm{CO}-\text { Heat }
$$

Water gas shift reaction:

$$
\mathrm{H}_{2} \mathrm{O}+\mathrm{CO} \leftrightarrow \mathrm{CO}_{2}+\mathrm{H}_{2}-\text { Heat }
$$

Methanation reaction:

$$
\mathrm{C}+2 \mathrm{H}_{2} \rightarrow \mathrm{CH}_{4}+\text { Heat }
$$
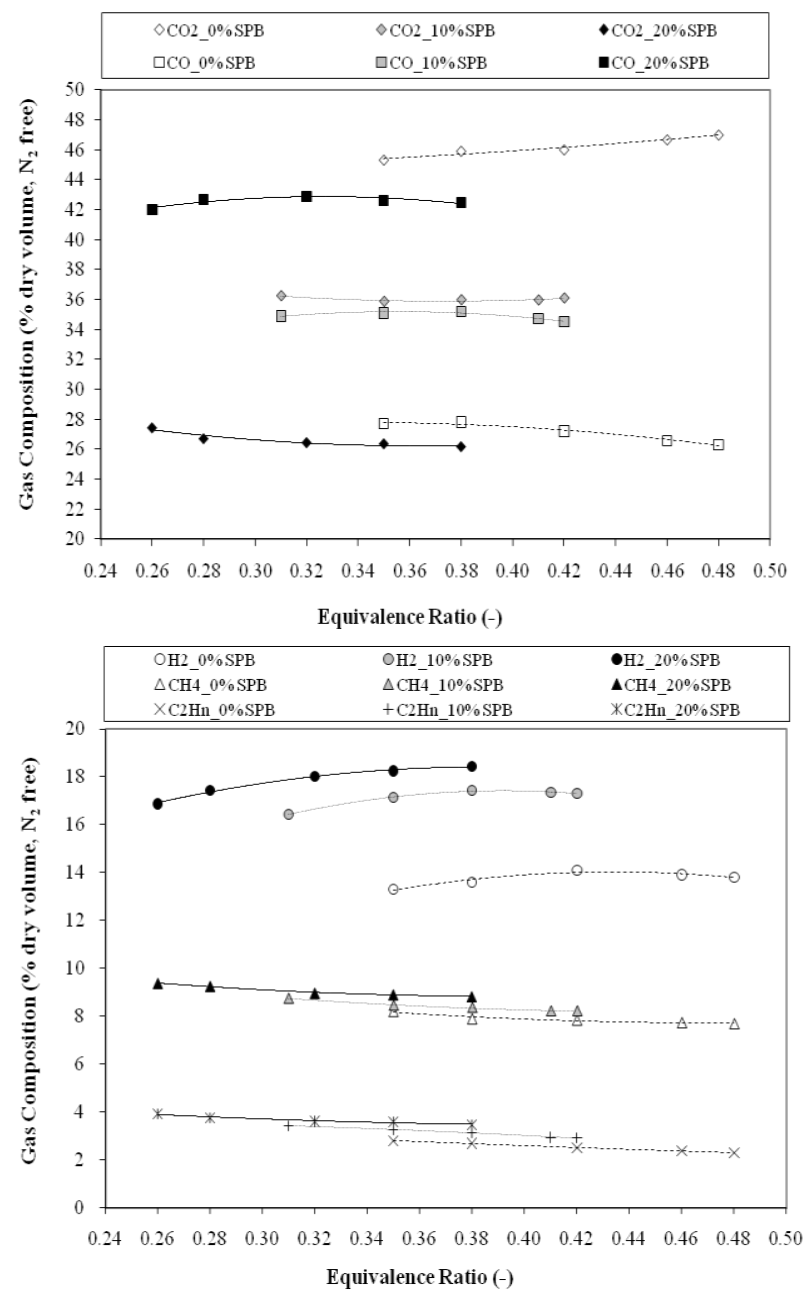

Fig. 2. Product gas composition at various ERs and proportions of SPB in the fuel mixtures.

Considering all the processes mentioned above, the product gas composition after the fuel mixtures were gasified is investigated in this part. Fig. 2 shows that $\mathrm{CO}_{2}$ generation was diminished while $\mathrm{CO}$ and $\mathrm{H}_{2}$ release were increased with increasing the weight proportion of SPB in the fuel mixture at all ERs. This is probably due to the increase of reactor temperature with increasing the SPB in the fuel mixture as presented in Fig. 1. The average bed temperature of high-moisture rubber woodchip gasification (i.e. 0\% SPB, $27 \%$ M.C.) was around $700-750^{\circ} \mathrm{C}$ at $\mathrm{ER}$ in the range of $0.35-0.48$. Within this range of temperature, the water gas shift reaction, refer to (11), was probably one of the most important reactions defining the final gas composition. While the average bed temperature of $10 \%$ and $20 \%$ SPB in the fuel mixture increased to $750-800^{\circ} \mathrm{C}$ at $\mathrm{ER}$ in the range of $0.26-0.43$, the forward reaction of water gas reaction and
Boudouard reaction, refer to (9) and (10), were favored resulting in the reduction of $\mathrm{CO}_{2}$ formation and increasing of $\mathrm{CO}$ and $\mathrm{H}_{2}$ production [12], [21]. The production of $\mathrm{CH}_{4}$ and $\mathrm{C}_{2} \mathrm{H}_{\mathrm{n}}$ also increased as the weight proportion of SPB increased in the fuel mixture for all ERs due to the plastic cracking, rather than the methanation reaction [22]. Adding SPB in the fuel mixture resulted in the higher content of hydrogen and carbon as seen in Table II, which means that the reactants are increased, so this might also be part of the reason why $\mathrm{H}_{2}, \mathrm{CO}, \mathrm{CH}_{4}$, and $\mathrm{C}_{2} \mathrm{H}_{\mathrm{n}}$ release were increased.

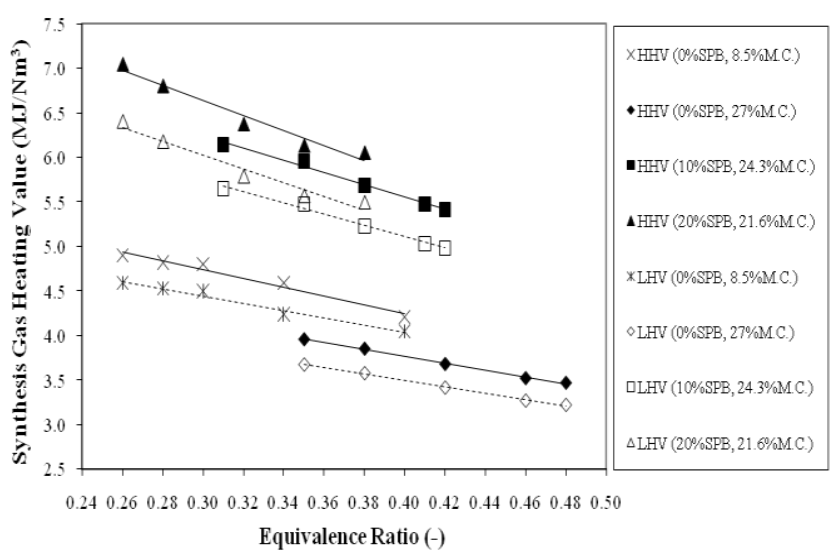

Fig. 3. Synthesis gas heating value at various ERs and proportion of SPB in the fuel mixture compared with that of pre-dried rubber woodchip.

The effect of moisture content and the SPB proportion in the fuel mixture on the synthesis gas heating value, in term of higher heating value (HHV) and lower heating value (LHV), is shown in Fig. 3. The high-moisture rubber woodchip (i.e. $0 \%$ SPB, 27\%M.C.) produced synthesis gas having HHV and LHV lower than those of the pre-dried rubber woodchip (i.e. $0 \%$ SPB, $8.5 \%$ M.C.) by about $0.5 \mathrm{MJ} / \mathrm{Nm}^{3}$ for all ERs. By adding SPB in the fuel mixture even at $10 \%$ by weight, both HHV and LHV were increased by more than $50 \%$ that is from 3.5-4.0 MJ/ $/ \mathrm{Nm}^{3}$ to $5.3-6.3 \mathrm{MJ} / \mathrm{Nm}^{3}$. This is likely caused by the relatively high hydrocarbon contents of SPB in the fuel mixture (refer to Table II). However, the further increase in $\%$ SPB only slightly improved the heating value of the product gas. Considering all mixture cases, the increase in ER reduced the synthesis gas heating value due to the more available $\mathrm{O}_{2}$ favoring oxidation reaction as well as the effect of $\mathrm{N}_{2}$ dilution. This is in line with the observation of the other studies [20], [21].

\section{Improvement of Carbon Conversion Efficiency}

Carbon conversion efficiency or the ability to convert carbon in solid phase into gas phase was also investigated in this study. It is calculated as the ratio between the amount of carbon in product gases (i.e. $\mathrm{CO}, \mathrm{CO}_{2}, \mathrm{CH}_{4}$ and $\mathrm{C}_{2} \mathrm{H}_{\mathrm{n}}$ ) and the amount of carbon in the fuel feeding [23]. The carbon conversion efficiency at various ER and proportions of SPB in the fuel mixture compared with that of low-moisture rubber woodchip is displayed in Fig. 4. As expected, the carbon conversion efficiency for all ERs significantly dropped when the moisture content of the rubber woodchip was increased from 8.5 to $27 \%$. With $20 \%$ mixing of SPB in the high-moisture rubber woodchip (i.e. $0 \% \mathrm{SPB}, 27 \% \mathrm{M}$.C.) the carbon conversion efficiency could be improved to reach the level of pre-dried rubber woodchip (i.e. $0 \%$ SPB, $8.5 \%$ M.C.). 
TABLE III: COMPARISON OF GASIFICATION PERFORMANCE AT VARIOUS PROPORTION OF SPB AND SRW ADDITION IN High-MOISTURE RUBBER WOOdCHIP

\begin{tabular}{lcccccc}
\hline \multicolumn{7}{c}{ AT ER $=0.38$} \\
\hline Fuel Mixtures & $0 \%$ SPB & $0 \%$ SRW & $10 \%$ SPB & $10 \%$ SRW & $20 \%$ SPB & $20 \%$ SRW \\
\hline Average bed temperature $\left({ }^{\circ} \mathrm{C}\right)$ & 730 & 729 & 790 & 765 & 810 & 788 \\
Gas composition (\%dry volume, $\mathrm{N}_{2}$ free) & & & & & \\
$\mathrm{CO}_{2}$ & 45.91 & 45.90 & 35.97 & 41.00 & 26.16 & 38.00 \\
$\mathrm{CO}$ & 27.81 & 27.80 & 35.19 & 32.20 & 42.47 & 32.95 \\
$\mathrm{H}_{2}$ & 13.61 & 13.60 & 17.43 & 14.40 & 18.44 & 15.80 \\
$\mathrm{CH}_{4}$ & 7.90 & 7.90 & 8.36 & 7.85 & 8.83 & 8.40 \\
$\mathrm{C}_{2} \mathrm{H}_{\mathrm{n}}$ & 2.70 & 2.70 & 3.13 & 2.75 & 3.47 & 2.49 \\
Higher heating value $\left(\mathrm{MJ} / \mathrm{Nm}^{3}\right)$ & 3.85 & 3.85 & 5.69 & 4.35 & 6.06 & 4.43 \\
Carbon conversion efficiency $(\%)$ & 74.45 & 74.45 & 86.20 & 80.00 & 95.30 & 86.20 \\
\hline \hline
\end{tabular}

Moreover, increasing ER could effectively increase the carbon conversion efficiency at all feedstock conditions. However, the higher availability of air at high ER gives a negative effect on the heating value of product gas, as discussed in the previous section.

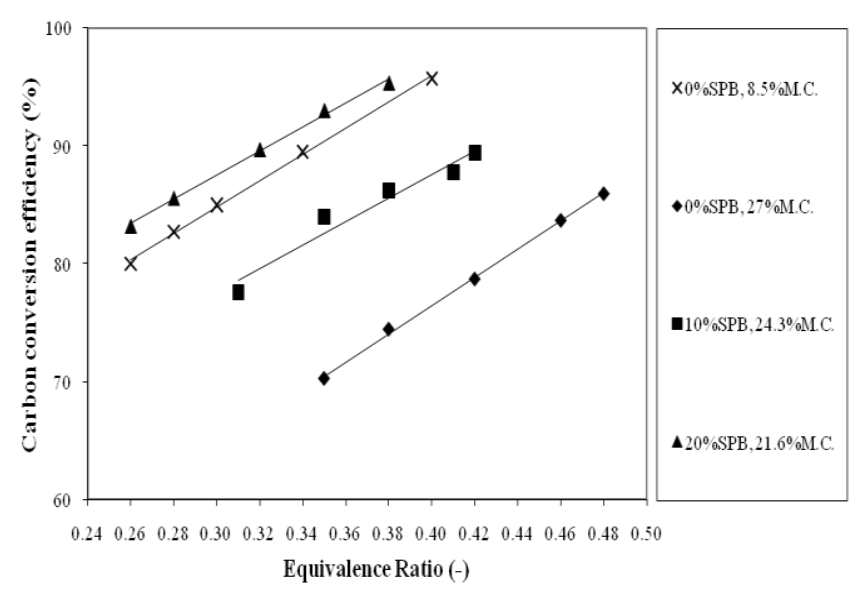

Fig. 4. Carbon conversion efficiency at various ERs and proportions of SPB in the fuel mixture compared with that of pre-dried rubber woodchip.

\section{E. A Comparison between Using SPB and SRW to Mix with a High-Moisture Rubber Woodchip}

To investigate the effect of mixing fuel types, the gasification improvement by mixing SPB with a high-moisture rubber woodchip (from this study) was compared with the use of SRW reported in the previous study [11]. The $\mathrm{ER}=0.38$ was selected for comparison since it was found to be the optimum value for gasification in the earlier gasification study [17] using the same gasifier and rubber woodchip of similar properties.

Table III presents the results including the average bed temperature, product gas composition and HHV, and carbon conversion efficiency. Considering the base case of the high-moisture rubber woodchip gasification (i.e. 0\%SPB) resulted from this study and resulted from the previous study (i.e. $0 \% \mathrm{SRW}$ ), all results are almost identical, which then ensure a fair comparison of the effect of SPB and SRW addition.

Both cases with SPB and SRW additions show a similar trend to significantly improve the product gas quality and carbon conversion efficiency. However, the SPB addition at the same mixing proportion affected gasification to a greater extent. For each $10 \%$ increase in SPB addition, the carbon conversion efficiency was improved by around $10 \%$, while around $6 \%$ was observed for the SRW addition. This may be explained by the higher average bed temperature in the case of SPB addition. The increase in $\mathrm{CO}$ and $\mathrm{H}_{2}$ content was also larger with SPB addition. Especially at $20 \%$ mixing proportion, the contents of $\mathrm{CO}$ and $\mathrm{H}_{2}$ were significantly increased by almost $50 \%$, while the content of $\mathrm{CO}_{2}$ was reduced by almost half. This therefore results in a much higher $\mathrm{HHV}$ of the product gas, i.e. increasing from 3.85 to $6.06 \mathrm{MJ} / \mathrm{Nm}^{3}$. With $10 \% \mathrm{SRW}$ addition, the increase in CO and $\mathrm{H}_{2}$ content was much less. Moreover, the further increase in the mixing proportion of SRW, despite improving carbon conversion efficiency, was found not so beneficial for the gas quality improvement. The higher increase in $\mathrm{CO}$ and $\mathrm{H}_{2}$ for the SPB addition is likely due to the higher $\mathrm{C}$ and $\mathrm{H}$ content, higher heating value and the lower moisture content of SPB (refer to Table I). These also led to the higher reaction temperature (as shown in Table III), which favored the production of $\mathrm{H}_{2}$.

\section{CONCLUSIONS}

In this study, the potential of co-gasification of high-moisture rubber woodchip mixed with plastic waste (SPB) at different weight ratios was investigated in a bubbling fluidized bed gasifier. The results were also compared with the case of pre-dried rubber woodchip and high-moisture rubber woodchip mixed with rubber waste (SRW). The SPB addition was found to significantly improve the gasification performance, both the product gas quality and carbon conversion efficiency. Even at $10 \%$ mixing ratio, the HHV of the product gas increased by about $50 \%$ and $25 \%$ compared to the case of high-moisture rubber woodchip and pre-dried rubber woodchip, respectively. At $20 \%$ mixing ratio, the $\mathrm{HHV}$ of product gas was increased from 3.85 (the case of high-moisture rubber woodchip) to $6.06 \mathrm{MJ} / \mathrm{Nm}^{3}$. The carbon conversion efficiency could be significantly improved to reach the level of the pre-dried rubber woodchip when mixing with $20 \%$ SPB. When compared to SRW addition at the same weight ratio, i.e. 10 and $20 \%$, and ER, i.e. 0.38 , both cases with SPB and SRW additions show a similar trend to significantly improve the product gas quality and carbon conversion efficiency. However, the SPB addition at the same mixing proportion affected gasification to a greater extent. From the results obtained, the co-gasification with plastic waste can be considered as a promising solution for utilizing high-moisture biomass like rubber woodchip. Moreover, it can also be an effective way for waste management because not only the waste is eliminated but also used as fuel. 


\section{ACKNOWLEDGMENT}

The authors gratefully acknowledge the National Research University Project of Thailand's Office of the Higher Education Commission.

\section{REFERENCES}

[1] F. Jurado, A. Cona, and J. Carpio, "Modelling of combined cycle power plants using biomass," Renewable Energy, vol. 28, pp. 743-753, 2003.

[2] R. W. Breault, "Gasification processes old and new: A basic review of the major technologies," Energies, vol. 3, pp. 216-240, February 2010.

[3] S. Pipatmanomai, "Overview and experiences of biomass fluidized bed gasification in Thailand," Journal of Sustainable Energy \& Environment Special Issue, pp. 29-33, 2011.

[4] W. E. M. Hughes and E. D. Larson, "Effect of fuel moisture content on biomass-IGCC performance," Journal of Engineering for Gas Turbines and Power, vol. 120, pp. 455-459, 1998.

[5] L. Wilson and G. R. John, "Effects of moisture content in biomass gasification," in Proc. Second International Conference on Advances in Engineering and Technology, 2011, pp. 565-571.

[6] A. Sanz and J. Corella, "Modeling circulating fluidized bed biomass gasifiers. Results from a pseudo-rigorous 1-dimensional model for stationary state," Fuel Processing Technology, vol. 87, pp. 247-258, 2006.

[7] Y. L. Lyubina and A. L. Suris, "Thermodynamic model of the plasma gasification of organic solid waste," Chemical and Petroleum Engineering, vol. 35, pp. 403-406, 1999.

[8] E4Tech, Review of Technologies for Gasification of Biomass and Wastes - Final Report, NNFCC Project 09/008, 2009.

[9] D. C. Elliott, "Catalytic hydrothermal gasification of biomass," Biofuels Bioproducts \& Biorefining, vol. 2, pp. 254-265, April 2008.

[10] R. N. André, F. Pinto, C. Franco, M. Dias, I. Gulyurtlu, M. A. A. Matos, and I. Cabrita, "Fluidised bed co-gasification of coal and olive oil industry wastes," Fuel, vol. 84, pp. 1635-1644, March 2005.

[11] S. Kaewluan and S. Pipatmanomai, "Gasification of high moisture rubber woodchip with rubber waste in bubbling fluidized bed," Fuel Processing Technology, vol. 92, pp. 671-677, 2011.

[12] F. Pinto, C. Franco, R. N. André, M. Miranda, I. Gulyurtlu, and I. Cabrita, "Co-gasification study of biomass mixed with plastic wastes," Fuel, vol. 81, pp. 291-297, 2002.

[13] H. P. Schiffer and W. Adlhoch, "Co-gasification of used plastics at the HTW demonstration plant: results from R\&D activities," Braunkohle, vol. 47, pp. 19-25, 1995.

[14] R. Davison, Coprocessing Waste with Coal, IEA Coal Research, 1997.

[15] Y. C. Choi, J. G. Lee, J. H. Kim, T. J. Park, and J. H. Kim, "High temperature air-blown gasification of Korean anthracite and plastic waste mixture," Korean J. Chem. Eng., vol. 24, no. 4, pp. 706-710, 2007.

[16] L. Wang, V. L. Weller, D. D. Jones, and M. A. Hanna, "Review contemporary issues in thermal gasification of biomass and its application to electricity and fuel production," Biomass and Bioenergy, vol. 32, pp. 573-581, February 2008.

[17] S. Kaewluan and S. Pipatmanomai, "Potential of synthesis gas production from rubber wood chip gasification in a bubbling fluidised bed gasifier," Energy Conversion and Management, vol. 52, no. 1, pp. 75-84, 2011
[18] L. Waldheim and T. Nilsson, "Heating value of gases from biomass gasification," Report Prepared for IEA Bioenergy Agreement-Thermal Gasification of Biomass, p. 3, May 2001

[19] H. Morita, F. Yoshiba, N. Woudstra, K. Hemmes, and H. Spliethoff, "Feasibility study of wood biomass gasification/molten carbonate fuel cell power system-comparative characterization of fuel cell and gas turbine systems," Journal of Power Sources, vol. 138, pp. 31-40, August 2004.

[20] R. Xiao, B. Jin, H. Zhou, Z. Zhong, and M. Zhang, "Air gasification of polypropylene plastic waste in fluidized bed gasifier," Energy Conversion and Management, vol. 48, pp. 778-786, 2007.

[21] M. P. Aznar, M. A. Caballero, J. A. Sabcho, and E. Francés, "Plastic waste elimination by co-gasification with coal and biomass in fluidized bed with air in pilot plant," Fuel Processing Technology, vol. 87, pp. 409-420, 2006.

[22] P. García-Bacaicoa, J. F. Mastral, J. Ceamanos, C. Berrueco, and C. Serrano, "Gasification of biomass/high density polyethylene mixtures in a downdraft gasifier," Bioresource Technology, vol. 99, pp. 5485-5491, 2008.

[23] P. Basu, Combustion and Gasification in Fluidized Beds, Taylor\&Francis Group: Boca Raton, Florida, USA, ch. 3, pp. 92-94, 2006.

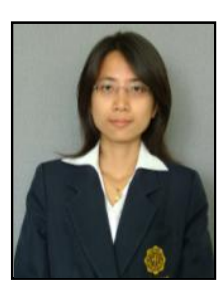

P. Chobthiangtham was born in Bangkok, Thailand. In 1999, she received her bachelor degree in environmental engineering from Suranaree University of Technology, Nakhon Ratchasima, Thailand. She then completed her master degree in environmental engineering from King Mongkut's Unversity of Technology Thonburi, Bangkok, Thailand in 2003. Now she is a Ph.D. candidate of energy technology in The Joint Graduate School of Energy and Environment at King Mongkut's Unversity of Technology Thonburi, Bangkok, Thailand She has also served as a lecturer for the Department of Civil Engineering, Faculty of Engineering, Srinakharinwirot University since 2012. Her research interests include but not limited to the waste utilization, solidification, biomass gasification and computational fluid dynamic simulation.

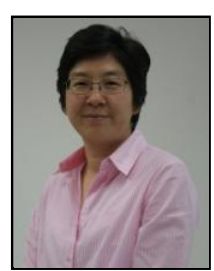

S. Fukuda was born in Bangkok, Thailand. She received her bachelor degree in chemical technology from Chulalongkorn University, Bangkok, Thailand in 1996, then master degree of science and doctor degree of philosophy in chemical engineering from Imperial College, London, UK, in 1998 and 2002, respectively. She has worked at the Energy Division of the Joint Graduate School of Energy and Environment, King Mongkut's University of Technology Thonburi in Bangkok, Thailand since 2004 as a lecturer. Currently, she holds an associate professorship as well as management position as the chair of energy division. She has carried out extensive research in the field of solid fuel utilization for energy, from basic science to engineering, including bioenergy and biofuel production, clean coal technology and energy system engineering. She has 47 publications in peer-reviewed journals and conferences of international repute and has involved in a number of international and national projects with high national and industrial impact. She also gives a significant contribution as a peer reviewer for various reputed international journals. 